University of Nebraska - Lincoln

DigitalCommons@University of Nebraska - Lincoln

Agronomy \& Horticulture -- Faculty Publications

Agronomy and Horticulture Department

2017

\title{
Regeneration and invasion of cottonwood riparian forest following wildfire
}

\author{
Carissa L. Wonkka \\ University of Nebraska-Lincoln, cwonkka2@unl.edu \\ Dirac L. Twidwell Jr. \\ University of Nebraska-Lincoln, dirac.twidwell@unl.edu \\ Christine H. Bielski \\ University of Nebraska-Lincoln, christine.bielski@huskers.unl.edu \\ Craig R. Allen \\ University of Nebraska-Lincoln, callen3@unl.edu \\ Michael C. Stambaugh \\ University of Missouri - Columbia, stambaughm@missouri.edu
}

Follow this and additional works at: https://digitalcommons.unl.edu/agronomyfacpub

Part of the Agricultural Science Commons, Agriculture Commons, Agronomy and Crop Sciences Commons, Botany Commons, Horticulture Commons, Other Plant Sciences Commons, and the Plant Biology Commons

Wonkka, Carissa L.; Twidwell, Dirac L. Jr.; Bielski, Christine H.; Allen, Craig R.; and Stambaugh, Michael C., "Regeneration and invasion of cottonwood riparian forest following wildfire" (2017). Agronomy \& Horticulture -- Faculty Publications. 1027.

https://digitalcommons.unl.edu/agronomyfacpub/1027

This Article is brought to you for free and open access by the Agronomy and Horticulture Department at DigitalCommons@University of Nebraska - Lincoln. It has been accepted for inclusion in Agronomy \& Horticulture -Faculty Publications by an authorized administrator of DigitalCommons@University of Nebraska - Lincoln. 


\title{
Regeneration and invasion of cottonwood riparian forest following wildfire
}

\author{
Carissa L. Wonkka ${ }^{1,2}$, Dirac Twidwell ${ }^{1}$, Christine H. Bielski ${ }^{1}$, Craig R. Allen ${ }^{3}$, \\ Michael C. Stambaugh ${ }^{4}$
}

Populus deltoides is considered to be a weak resprouter and highly susceptible to wildfire, but few post-wildfire studies have tracked $P$. deltoides response and resprouting within the Great Plains of North America. Following a wildfire in southwestern Kansas, U.S.A., we surveyed burned and unburned areas of a cottonwood riparian forest along the Cimarron River that included a major understory invader, tamarisk (Tamarix ramosissima Ledeb.). We tested the following hypotheses, which are consistent with the current understanding of $\boldsymbol{P}$. deltoides response to wildfire in the Great Plains: (1) regeneration of $P$. deltoides will be low in areas burned by the wildfire; $(2)$ the number of dead $P$. deltoides individuals will be greater in the wildfire than unburned areas; and (3) tamarisk regeneration will be higher than $P$. deltoides regeneration in the wildfire areas because tamarisk is considered a stronger resprouter. We found evidence contrary to two of our hypotheses 3 years following the wildfire. (1) P. deltoides regeneration was high following the wildfire, averaging 692 individuals/ha. (2) The number of dead mature cottonwood trees was greater in wildfire plots than in unburned plots. (3) There was more $P$. deltoides regeneration than tamarisk regeneration following wildfire. These findings, which diverge from the majority of studies examining $P$. deltoides regeneration in the Great Plains, suggest that differing local environmental and forest stand conditions, coupled with the timing and intensity of the fire, could be important determinants of riparian forest species' responses to wildfire.

Key words: Cimarron River, Populus deltoides, resprouting, riparian forest regeneration, tamarisk, wildfire

\section{Implications for Practice}

- High-intensity fire is becoming more frequent in the Great Plains. Therefore, a better understanding of $P$. deltoides riparian forest response to fire is necessary to ensure its persistence.

- Resprouting response to wildfire differs among Populus species and from location to location. Therefore, species and location-specific data are necessary for effective riparian forest restoration planning.

- Our findings showcase the need for a greater network of post-disturbance surveys that explore the drivers of divergent responses of resprouting trees. Such an approach would enhance our understanding of conditions necessary for ensuring riparian forest persistence in a future with uncertain global drivers.

\section{Introduction}

Concern over declines in cottonwood recruitment and the eventual loss of cottonwood riparian forests has spurred major restoration initiatives across their range (Rood \& Mahoney 1990). Recruitment limitation is considered to be the biggest threat to the long-term persistence of riparian cottonwood forests (Dreesen et al. 2002; Rood et al. 2003b). Management recommendations have therefore emphasized planting new cottonwood trees while protecting old, mature cottonwood stands from extreme disturbance events (Fick \& Geyer 2010; Colorado State Forest Service 2015). In addition, in many areas, managers are concerned because Tamarix and Juniperus spp. dominate the understory of many old cottonwood stands as a result of a lack of disturbance and appear poised to succeed cottonwood riparian forests in the future (Sudbrock 1993); additionally, many other understory species are changing the community structure of riparian forests (Nemec et al. 2013). In response, restoration of these stands often includes intensive chemical and mechanical removal of woody invaders from the understory (Friedman et al. 2005). Prioritization of planting and intensive exotic species control is not unique to cottonwood riparian forests in North America. A recent review of restoration activities for riparian vegetation worldwide showed native planting and exotic species control to be ubiquitous in published restoration studies (González et al. 2015).

Human activities have greatly altered disturbance regimes in cottonwood riparian forests relative to pre-settlement historical

Author contributions: CLW, DT conceived and designed the research; CLW analyzed the data; CLW, DT, CHB, CRA, MCS wrote and edited the manuscript.

${ }^{1}$ Department of Agronomy \& Horticulture, University of Nebraska-Lincoln, Lincoln, NE 68583, U.S.A.

${ }^{2}$ Address correspondence to C. L. Wonkka, email cwonkka2@unl.edu

${ }^{3}$ U.S. Geological Survey, Nebraska Cooperative Fish and Wildlife Research Unit, School of Natural Resources, University of Nebraska, Lincoln, NE 68583, U.S.A.

${ }^{4}$ Department of Forestry, University of Missouri, Columbia, MO 65411, U.S.A.

(C) 2017 Society for Ecological Restoration

doi: $10.1111 /$ rec. 12577

This document is a U.S. government work and is not subject to copyright in the United States. 
contexts. Human alteration of riparian hydrologic regimes, especially a reduction in variability of flood events, has driven a switch from asynchronous to synchronous cottonwood stands with low seedling recruitment (Gom \& Rood 2000; Lytle \& Merritt 2004). River damming and flow modification have reduced peak flows, resulting in fewer flood events and completely eliminating extreme flooding in many cottonwood riparian forests (Palmer et al. 2008). Prior to engineering of rivers and streams in the early twentieth century, flooding and the meandering of alluvial rivers created patches suitable for seedling recruitment. This led to a dynamic mosaic of cottonwood stands ranging from young, early successional patches to older "climax" patches. In addition, cottonwood riparian forests are also subject to fires of differing intensities especially in the Great Plains of North America where riparian cottonwood forests are situated within a grassland matrix. Periods of drought frequently occur in central and western North America (Stambaugh et al. 2011), which provided occasions for high-intensity crown fires to impact riparian cottonwood forests (Dwire \& Kauffman 2003). Many cottonwood species resprout following wildfire (Gom \& Rood 2000). Populus deltoides, however, is considered to be a weak resprouter in the Great Plains (Rood et al. 2007). Despite evidence that under some conditions, $P$. deltoides will resprout following fire (Ellis 2001; Smith et al. 2009), the dominant view of forest management agencies is that wildfire is catastrophic for $P$. deltoides forests throughout their range in the Great Plains. This is concerning because of the increase in wildfire occurrence across the Great Plains this decade, and the expectation for this trend to continue (Guyette et al. 2015).

Few studies, however, have tracked resprouting of $P$. deltoides following fire in the Great Plains, so information is lacking across this geographic range. Gom and Rood $(1999,2000)$ show that $P$. deltoides is a weak resprouter following fire relative to other cottonwood species in southern Alberta. No other studies have assessed the response of $P$. deltoides to fire in this region. However, findings from southwestern U.S.A. show that $P$. deltoides can resprout prolifically following wildfire (Ellis 2001), suggesting that even within a species, the local environment as well as pre- and post-fire conditions are important determinants of response to wildfire. The assumption of many managers in the Great Plains, given the information available, is that intensive restoration plantings are required following wildfire to sustain existing cottonwood forest throughout the region. The assumed lack of regeneration also creates the need for intensive management aimed at reducing exposure of taller and older cottonwood trees to fire. However, the resulting lack of disturbance enables Tamarix and Juniperus spp. invasion into the understory. As a result, restoration practitioners must also allocate time and money to intensive interventions that mechanically or chemically remove woody invaders. A better understanding of the resprouting and regeneration patterns of $P$. deltoides following wildfire could help identify alternative restoration methods for increasing regeneration of cottonwood riparian forests and, more generally, potential limitations in current riparian vegetation restoration plans worldwide. Large dam construction continues globally (Molles et al. 1998). As a result, altered flow regimes and degradation of riparian vegetation is a ubiquitous problem necessitating the identification of effective restoration interventions.

A 2011 wildfire on the Cimarron National Grasslands provided a unique opportunity to better understand $P$. deltoides resprouting and recruitment potential, and Tamarix spp. invasion following wildfire. The wildfire burned approximately $65 \%$ of the $P$. deltoides riparian forest on the national grasslands. Mechanical removal of dead cottonwood stems had not been conducted immediately after the fire and the riparian area is fenced to exclude livestock, allowing us to avoid these potentially confounding factors from an analysis of wildfire responses. Given information currently available regarding fire in $P$. deltoides riparian forests in the Great Plains, we expect fire to result in a change in forest structure with loss of older, tall trees and an absence of regeneration of younger age classes. In addition, we expect tamarisk invasion to increase following wildfire via an increase in seedlings and resprouting of mature trees in the wildfire area. We surveyed burned and unburned areas 3 years following the wildfire to test three hypotheses: (1) because $P$. deltoides is considered to be a weak resprouter in this region, regeneration will be minimal in areas burned by the wildfire; (2) dead $P$. deltoides individuals (top-killed trees) will be greater in the wildfire than in unburned areas; and (3) tamarisk regeneration will be higher than $P$. deltoides regeneration in the wildfire areas because it is considered a stronger resprouter than $P$. deltoides. Our objective is to provide evidence that supports, or alternatively allows improvement of, the current understanding regarding $P$. deltoides cottonwood forest response to fire in the Great Plains and, more broadly, identify important considerations for developing potential restoration alternatives to intensive management for riparian forest vegetation globally.

\section{Methods}

\section{Study Site}

Cimarron National Grassland $\left(37^{\circ} 7.29^{\prime} \mathrm{N}, 101^{\circ} 53.81^{\prime} \mathrm{W}\right)$ is comprised of 43,777 ha of shortgrass prairie grassland with a plains cottonwood (Populus deltoides ssp. monilifera (Ait.) Eckenwalder) riparian forest traversing the interior of the grassland along the floodplain of the Cimarron River. Tamarisk (Tamarix ramosissima Ledeb.) has become the dominant understory species across the cottonwood riparian area. Surveys of the Cimarron River Basin indicate that the Cimarron riparian corridor is $67 \%$ invaded by tamarisk in Morton County, where the Grassland is located (Kansas Water Office 2005). Cimarron National Grassland is located in southwest Kansas, U.S.A. where climate is considered semiarid with a mean annual precipitation of $400 \mathrm{~mm}$ and precipitation occurring predominantly during the growing season. The riparian area at Cimarron National Grassland is fenced to prevent livestock access. The Cimarron River was the focus of several previous studies, which provide a historic record of long-term changes in its morphology and vegetation (Schumm \& Lichty 1963; VanLooy \& Martin 2005). These studies provide insight from 1874 through 2001 on channel width and vegetation. The Cimarron 


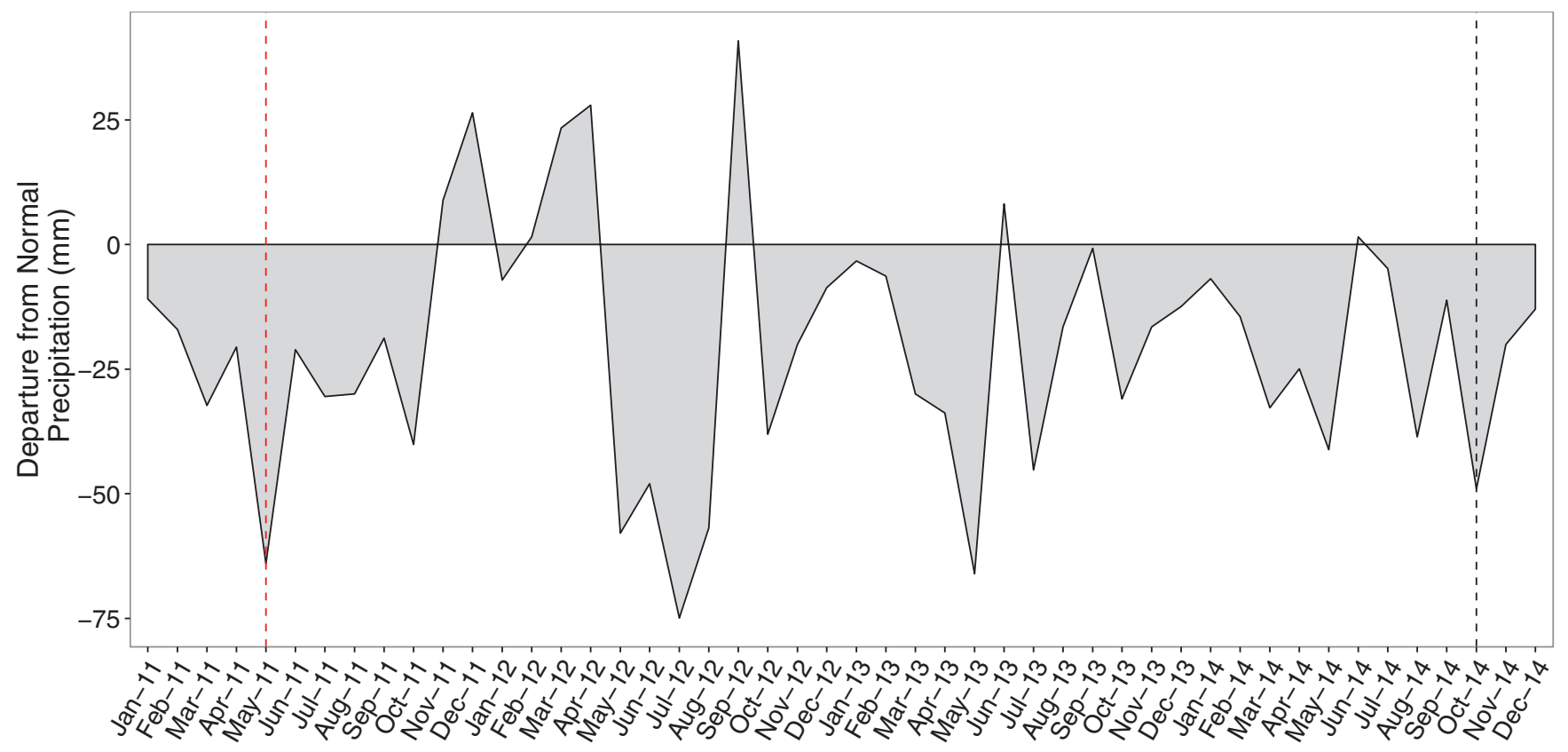

Figure 1. Precipitation departure from 30 year normal precipitation for Liberal KS (closest weather station to the study location) (National Oceanic and Atmospheric Administration 2016). The red dashed line indicates the occurrence of the Tunner Fire. The black dashed line indicates the timing of sampling.

River channel, which was a narrow meandering channel vegetated by grasses, began to widen after a major flood in 1914. It continued to widen until 1942, when above average annual precipitation and low peak flows allowed for accretion of sediment along the now wide, braided channel. Riparian trees and shrubs began to develop on islands, stabilizing the banks and capturing sediment. Over time, these vegetated islands became attached to the banks (Schumm \& Lichty 1963). This narrowing trend continued until 1991, when the entire floodplain was covered with riparian trees and shrubs, interspersed with grasses and weeds. From 1991 until 2001, the narrowing continued in some areas but slowed or reversed in others (VanLooy \& Martin 2005).

On 8-12 May, 2011, the Tunner wildfire burned 7,075 ha of the Cimarron National Grassland. At the time of the wildfire, $P$. deltoides in the riparian area typically have fully developed leaves and seeds that are beginning to form. Seeds are typically released in early June in this region. At the time of the Tunner Fire, the region was experiencing an extreme to exceptional drought (Palmer Drought Severity Index <-4.0; U.S. drought monitor; Fig. 1). The wildfire spread through the center of the national grassland, burning the central portion of the cottonwood forest, while leaving stretches of riparian vegetation that had not been burned to the east and west of the burned area (Fig. 2). The Tunner Fire was described by forest service officials as one of the most extreme wildfires in this region, with erratic fire behavior. In addition, a bulletin issued by the National Interagency Fire Center which is responsible for tracking fire behavior using advanced models in order to coordinate suppression declared that "the fire behavior is considered extreme at this time" on the afternoon of the second day of the fire. Drought conditions persisted following the wildfire, with below average precipitation through October 2011 (Fig. 1).
November and December 2011 had above average precipitation, but drought continued through the beginning of 2012 as well. The stretch of the Cimarron River crossing the national grassland is typically dry most of the year, but groundwater is typically found $30-45 \mathrm{~cm}$ below the channel surface (Cimarron National Grassland, unpublished data). Daily streamflow for the Cimarron River, as measured by a streamflow gauge in Morton County, KS (United States Geological Service Gauge 7,155,590, Cimarron River near Elkhart) was negligible both before the fire and for the intervening time period between the Tunner Fire and sampling in October 2014, with the only nonzero value, $48.1 \mathrm{~m}^{3} / \mathrm{s}$, occurring in October 2012 (U.S. Geological Survey 2016).

\section{Sampling Design and Data Collection}

We established $14100 \times 50 \mathrm{~m}$ plots along the riparian corridor. Half of the plots were randomly located in the area burned by the 2011 Tunner wildfire. The other seven plots were randomly located in the riparian area directly east and west of the wildfire (Fig. 2). In September 2014, we measured the height, stem/trunk diameter at breast height $(\mathrm{DBH})$, and number of stems for each cottonwood or tamarisk individual. Distinct cohorts were readily apparent as most individuals were either $<5 \mathrm{~cm}$ DBH or $>15 \mathrm{~cm}$ DBH. Cottonwood and tamarisk individuals were classified into categories based on size and condition: a mature individual with intact live foliage (live mature tree $>0.05 \mathrm{~m}$ $\mathrm{DBH}$ ), mature individual with no live foliage (dead mature tree $>0.05 \mathrm{~m} \mathrm{DBH}$ ), juvenile with intact live foliage (live juvenile $<0.05 \mathrm{~m} \mathrm{DBH}$ ), juveniles with no live vegetation (dead juvenile $<0.05 \mathrm{~m}$ DBH). Juveniles could be new individuals resulting from seed germination, clonal regeneration resulting 


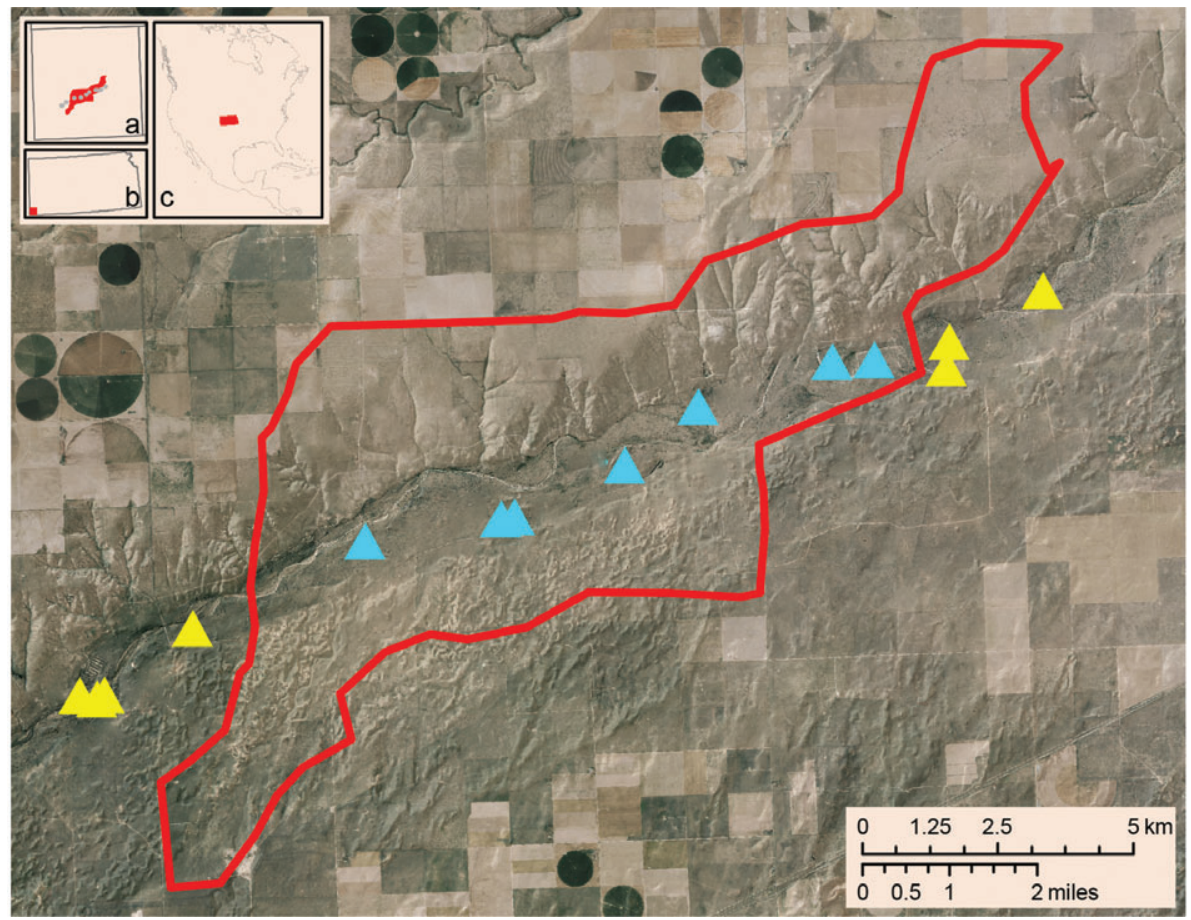

Figure 2. Map of Cimarron National Grassland with perimeter of the Tunner Fire outlined in red and location of sampling points denoted as triangles. Burned plots are identified with blue triangles and unburned with yellow triangles. All sampling occurred between 28 September 2014 and 14 October, 2014.

from lateral root suckering, clonal regeneration resulting from resprouting buried shoots, or clonal regeneration resulting from basal resprouting. We distinguished basal resprouts from the other categories of juveniles, but the other categories could not be distinguished from one another. Large tree heights (e.g. $>3 \mathrm{~m}$ ) were measured with a Nikon Forestry Pro Laser Rangefinder/Hypsometer. Shorter trees and resprouts were measured with a telescoping meter pole.

Elevation and distance to channel are thought to be important determinants of resprouting success and juvenile establishment because of the dependency of riparian cottonwoods in semiarid systems on alluvial water originating from stream flow (Rood et al. 2003a, 2003b). Therefore, we used a United Stated Department of Agriculture, Farm Service Agency, National Agriculture Imagery Program photo from 7 July, 2014 to determine the minimum distance from each plot to the river channel. We used ArcGIS to digitize the channel and measured the nearest distance to the channel from each plot. We used one-third arc-second (approximately $10 \mathrm{~m}$ resolution) Digital Elevation Models, a layer of the National Elevation Dataset developed by the USGS National Geospatial Program Office, to determine the average elevation of each plot to provide a proxy for distance to groundwater.

\section{Data Analysis}

To explore the differences in the number of cottonwoods and tamarisks in each age-class/status category in burned and unburned plots, we used generalized linear models (GLMs). We modeled the dependent variables (counts of cottonwood and tamarisk in each age-class/status category) as a function of treatment (burned or unburned) using a Poisson distribution and a log link function. In addition, we also compared number of recruits in burned plots for the two species to test hypothesis 3 using a GLM with a Poisson distribution and log link function (dependent variable: counts of recruits in burned plots, independent variable: species). In cases where biophysical process-pattern relationships are nonuniform and exhibit spatial structure in data, it is most appropriate to incorporate spatial autocorrelation into the statistical model (Legendre 1993). Because wildfire is a spatially contagious process, the effects of fire are often spatially autocorrelated as a result of spatial variation in fire behavior that results from differences in the spatial patterning of fuels and weather across a landscape (Twidwell et al. 2009). We tested for spatial autocorrelation in each response variable using a Mantel test to identify correlation between a distance matrix of the spatial location of each plot and a matrix of distances between values of each response variable. In cases where the Mantel test identified autocorrelation, we used the latitude and longitude of plots to determine a matrix of dissimilarities in distance among sampling points, following guidelines from Legendre (1993). We used principal coordinates of neighbor matrices (PCNM; Borcard \& Legendre 2002; Borcard et al. 2004; Dray et al. 2006) to extract the eigenvectors associated with positive eigenvalues for the distance matrix to obtain an approximation of spatial structures. These were added as independent variables to the GLM and a stepwise selection process was used to identify the PCNM eigenvectors that result in the best model fit. The resulting model 
accounts for spatial autocorrelation in the data at multiple spatial scales identified by the model selection process (Borcard et al. 1992).

To explore differences in overall age-class/status structure of cottonwoods where the wildfire burned and did not burn, we binned the heights of each cottonwood tree included in the study to establish a height distribution for wildfire and unburned areas. Bin widths were chosen at $0.53 \mathrm{~m}$ using the Freedman-Diaconis rule (Wand 1997) which establishes bin width with the equation:

$$
b=2^{*} I Q R^{*} n^{-1 / 3}
$$

We used Pearson's product-moment correlation to test for correlations between the proportion of top-killed trees that resprouted from the base in a plot and the following: plot elevation, nearest distance from plot to channel, average height of adult $P$. deltoides in the plot, and average DBH of adult $P$. deltoides in the plot. We also tested for correlations between the factors listed above and number of juveniles in the plot. We controlled the false discovery rate using the algorithm derived by Benjamini and Hochberg (1995).

\section{Results}

Plots burned in the wildfire differed from unburned plots, having extremely high levels of $P$. deltoides regeneration and topkill of a large proportion of adults. This finding is consistent with our second hypothesis regarding the effect of fire on adult $P$. deltoides. However, it counters our expectation of low regeneration following wildfire. In our study, unburned plots have a bimodal size distribution with moderate amounts of small and large size classes, but few trees in intermediate size classes (Fig. 3A). Burned plots, however, had high numbers of trees in small size classes and low numbers in the large size classes, with numbers tapering off as size increases (Fig. 3A). Regeneration was prolific in burned plots and largely absent from unburned plots (Fig. 3B). There were many more juveniles in burned plots than unburned plots $(z=-26.9, p<0.001)$. Burned plots had 629 juveniles per hectare on average, while unburned plots had 13. In burned plots, the percent of juveniles resulting from basal resprouting ranged from 5 to $12 \%$ (averaging $8.5 \%$ ). The majority of juveniles were either new individuals resulting from seed germination, clonal resprouts resulting from lateral root suckering, or clonal resprouts resulting from buried shoots. Number of dead juveniles did not differ between burned and unburned plots $(z=-0.004, p=0.997)$. There were more dead mature cottonwood trees, defined as top-killed trees, in burned plots $(z=-9.05, p<0.001)$. Burned plots had 33 dead mature trees per hectare on average, while unburned plots had 9 dead mature trees per hectare. Conversely, there were fewer live mature cottonwood trees in burned plots than in unburned plots $(z=3.86$, $p<0.001)$. There were 9 live mature trees per hectare on average in burned plots and 21 in unburned plots.

Tamarisk adults, dead adults, and juveniles differed between burned and unburned plots. The wildfire top-killed many adult tamarisk individuals, resulting in more live adults $(z=-2.24$, $p<0.025)$ and fewer dead adults $(z=-3.53, p<0.001)$ in unburned areas than in burned areas (Table 1). We also found several charred stumps that appeared to be tamarisk individuals in burned plots, suggesting that the average number of dead tamarisk individuals in burned plots is a conservative estimate. The number of juveniles was higher in burned plots than in unburned plots (Table $1 ; z=-16.11, p<0.001$ ). However, counter to our expectation in hypothesis 3 , the number of $P$. deltoides juveniles was higher than the number of tamarisk juveniles in the burned areas (Table $1 ; z=-25.61, p<0.001$ ), suggesting tamarisk regeneration is not outpacing $P$. deltoides regeneration in burned plots. Conversely, tamarisk regeneration is greater than $P$. deltoides regeneration in unburned areas (Table 1; $z=-25.61, p<0.001$ ). Burned plots also displayed great variability in response across the landscape. Standard errors for all age/status categories of cottonwood are large relative to those for unburned plots (Table 1).

Mantel tests revealed spatial autocorrelation among plots for tamarisk live adults and dead juveniles, therefore PCNM axes were included in those models according to model selection criteria. For adults, 3 axes were included and the resulting Akaike Information Criterion (AIC) was lowered from 45.02 (model without PCNM vectors) to 43.07. For dead recruits, 2 PCNM axes were included, reducing AIC from 32.98 to 28.9. No spatial autocorrelation was detected for any other age class/status for either species, suggesting that tamarisk individuals are likely patchily distributed across the landscape, but there were no spatial patterns in recruitment or mortality that resulted from the spread of fire across the landscape.

According to Pearson's product-moment tests, there was no correlation between either number of juveniles in a plot or proportion of top-killed adults resprouting from the base and any of the factors explored (plot elevation, nearest distance from plot to channel, average height of adult $P$. deltoides in the plot, and average $\mathrm{DBH}$ of adult $P$. deltoides in the plot; Table 2).

\section{Discussion}

Current restoration of riparian cottonwood forests seeks to increase recruitment by planting cottonwood seedlings, eliminating extreme disturbance events that shift the system away from a mature cottonwood stand, and reducing invasion into the understory, because recruitment limitation is viewed as the biggest barrier to their persistence (Dreesen et al. 2002; Rood et al. 2003b). Yet we found many $P$. deltoides juveniles 3 years following wildfire on the Cimarron National Grassland (an average of 692 recruits per hectare across the burned parts of the riparian forest). In contrast, the frequency of juveniles was low in unburned plots (an average of 14 recruits per hectare). Data from unburned plots suggest that unburned cottonwood stands are vulnerable to local extinction in this riparian forest. In unburned areas, the number of seedlings barely outpaced mortality of adult cottonwood from drought or natural die-off and juveniles do not appear to be transitioning to larger size classes given the lack of intermediate-sized cottonwood trees in unburned areas. In addition, tamarisk regeneration is 


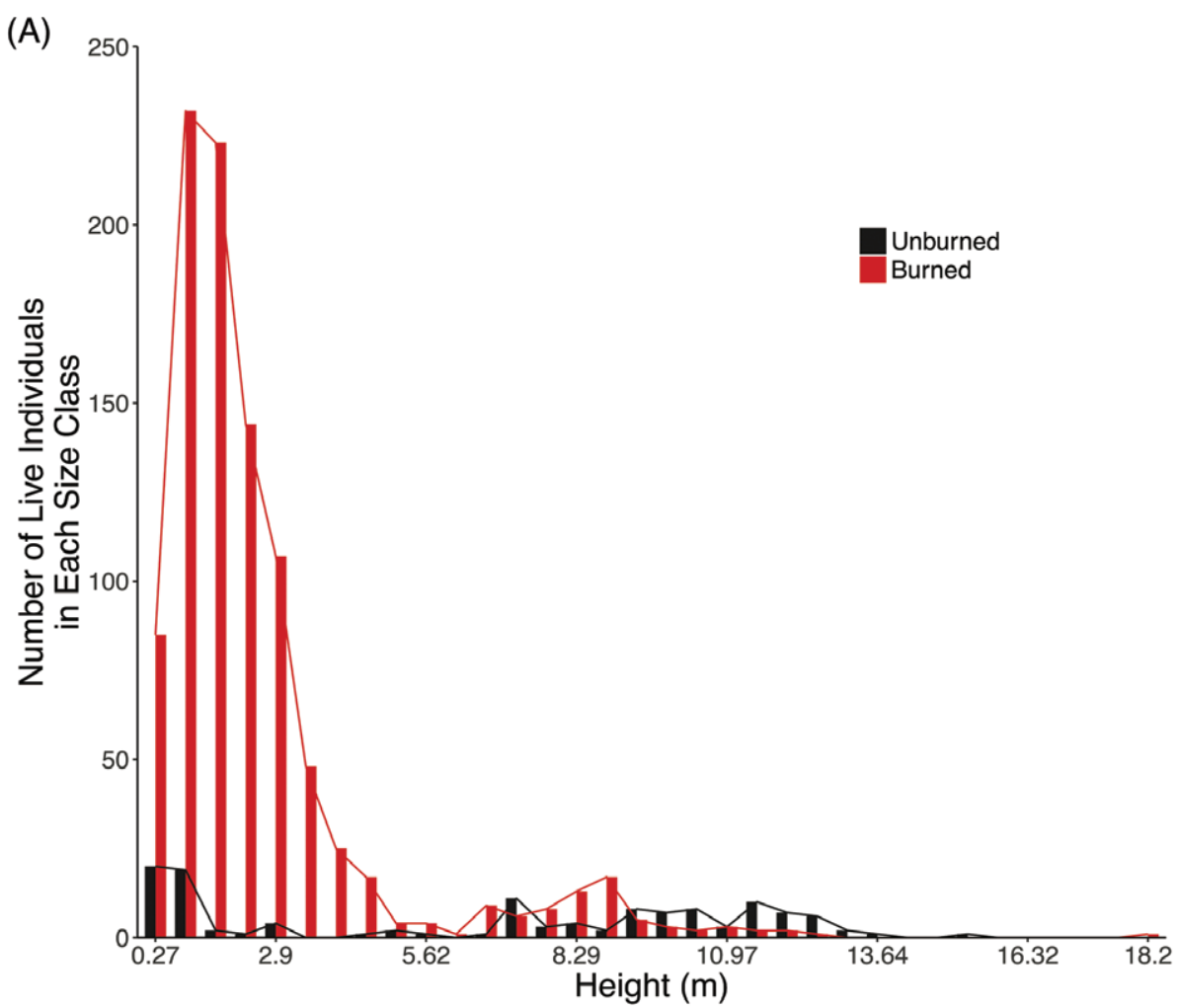

(B)

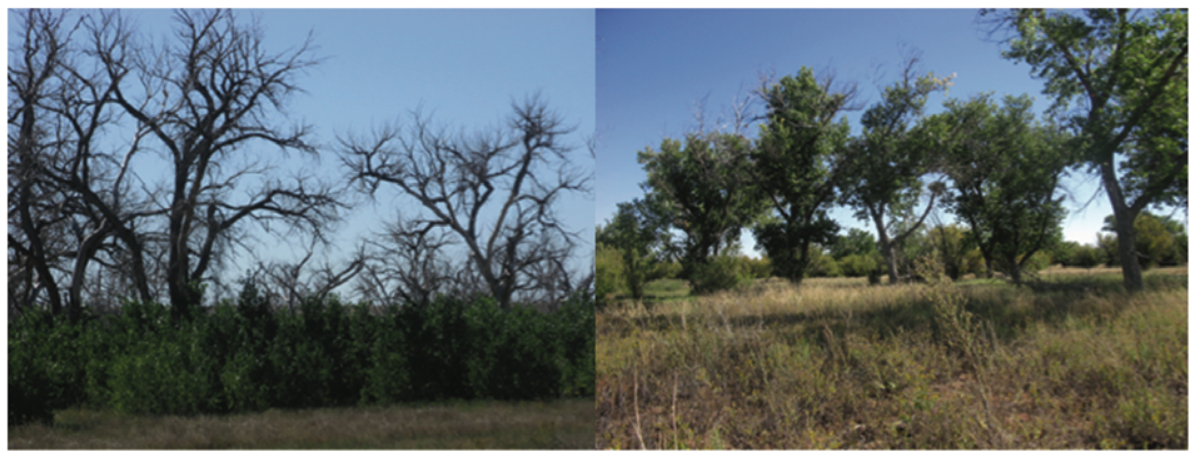

Figure 3. Differences in forest structure in burned and unburned areas. (A) shows the distribution of heights of cottonwood trees in the cottonwood riparian forest at Cimarron National Grassland in wildfire (red) and unburned (black) plots. (B) shows a burned plot 3 years following the Tunner Fire on the left and an unburned portion of the riparian forest on the right.

outpacing $P$. deltoides regeneration in unburned areas, suggesting the potential for tamarisk to replace $P$. deltoides in these stands.

This study demonstrates that $P$. deltoides, like other cottonwood species, can exhibit prolific resprouting following wildfire. We found that an average of $60 \%$ of top-killed P. deltoides had basal resprouts 3 years following fire. Our study was an advantageous survey of post-wildfire response, and as such is unreplicated. However, this response is not unique to our study area at Cimarron National Grassland. On the Rio Grande river in New Mexico, U.S.A., approximately $50 \%$ of another subspecies of $P$. deltoides, Rio Grande cottonwood (P. deltoides ssp. wislizeni (S. Wats.) Eckenwalder), top-killed in a wildfire, resprouted from either roots or shoots (Ellis 2001); another study from the Middle Rio Grande river in central New Mexico found high resprouting as well (Smith et al. 2009). In addition, although not the result of fire, hundreds of new P. deltoides stem and sprout shoots were found after major ice damage to a riparian forest in eastern Montana, U.S.A. (Smith \& Pearce 2000), suggesting that $P$. deltoides can indeed resprout prolifically. Lab experiments also show that $P$. deltoides is capable of producing root suckers (Schier \& Campbell 1976). P. deltoides was found to have been produced through root suckers in a riparian forest in Arizona, U.S.A. (Howe \& Knopf 1991) and in another section Aigeiros cottonwood, Fremont's cottonwood (Populus fremontii, S. Wats.), was determined to have been produced by root suckers in a riparian forest in Utah, U.S.A. (Irvine $\&$ West 1979). While we were unable to determine whether 
Table 1. Mean \pm SE numbers of cottonwoods per hectare of different age-class/status categories in burned and unburned plots. Bold numbers include pairs that differ significantly between wildfire and unburned areas.

\begin{tabular}{|c|c|c|c|c|}
\hline & Dead Mature Trees & Dead Juveniles & Live Mature Trees & Live Juveniles \\
\hline Burned & $33.43 \pm 6.50$ & $5.71 \pm 1.27$ & $9.43 \pm 4.78$ & $692.29 \pm 444.65$ \\
\hline \multicolumn{5}{|l|}{ Tamarisk } \\
\hline Burned & $10.57 \pm 7.77$ & $0.29 \pm 0.29$ & $2.57 \pm 2.26$ & $253.43 \pm 156.55$ \\
\hline Unburned & $3.14 \pm 1.74$ & $4.00 \pm 1.95$ & $19.71 \pm 7.61$ & $86.86 \pm 38.28$ \\
\hline
\end{tabular}

Table 2. Results for Pearson's product-moment correlation between both number of juveniles in a plot and proportion of topkilled adults resprouting from the base and each of the following factors: plot elevation, nearest distance from plot to channel (distance), average height of adult $P$. deltoides in the plot, and average DBH of adult $P$. deltoides in the plot. Correlation values fall between -1 and 1 with 0 indicating no association. Degrees of freedom for all tests are 12 , and the false discovery rate is controlled using the Benjamini-Hochberg algorithm.

\begin{tabular}{|c|c|c|c|c|}
\hline & Correlation & 95\% Confidence Interval & t Test Statistic & Adjusted $\mathrm{p}$ Value \\
\hline Juveniles:Distance & 0.59 & 0.09 to 0.85 & 2.54 & 0.21 \\
\hline Juvenile:DBH & -0.02 & -0.54 to 0.52 & -0.06 & 0.95 \\
\hline Resprouting:Elevation & -0.39 & -0.76 to 0.18 & -1.47 & 0.41 \\
\hline Resprouting:Distance & 0.36 & -0.21 to 0.75 & 1.34 & 0.41 \\
\hline
\end{tabular}

the majority of juveniles (those not the result of basal sprouting) were new recruits from seed or resprouting from roots or buried shoots, the burned areas in this study clearly exhibit the potential for regeneration of cottonwood stands following fire. However, for this potential to be realized, the long-term survival of these juveniles must be established. Little mortality of juveniles has been observed by Cimarron National Grassland staff as of May 2017, 6 years following fire (L. Brown 2017, personal communication). This is encouraging and suggests that there might be conditions under which $P$. deltoides riparian forest can recover following fire. Follow-up studies should be conducted to determine if these juveniles ultimately grow to maturity and replace adults killed by the Tunner Fire. In addition, data on the ontogeny of juveniles could aid in the development of mechanistic models describing $P$. deltoides response to fire.

Agency reports often identify $P$. deltoides as a weak resprouter; however, our data, when taken together with those collected by Ellis (2001), Smith et al. (2009), Smith and Pearce (2000), and others, provide evidence that suggests that $P$. deltoides is capable of vigorous resprouting following wildfire. Data from several studies in the Great Plains of North America do support the premise that $P$. deltoides is a weak resprouter following wildfire (Gom \& Rood 1999, 2000; Rood et al. 2007). Differences between $P$. deltoides resprouting in these studies and both Ellis (2001) and Smith et al. (2009) could be due to high post-fire precipitation in the latter studies. However, we found prolific resprouting in our study as well and drought continued for a long period of time following the Tunner wildfire. In addition, the timing of the post-fire data collection could be important. The Ellis (2001) study was conducted 2 years following fire and the Smith et al. (2009) study was 4 years following fire. They found that survival of resprouts was lowest in the first year following fire and generally increased over time. Our study and follow-up conversations with National Grassland personnel suggest that there is little mortality of juveniles 6 years after the fire. Smith et al. (2009) found that survival of resprouts was related to depth to groundwater. At the Cimarron National Grassland, groundwater is typically available within $30-45 \mathrm{~cm}$ below the surface on the soils that the riparian forest overlays. In semiarid regions, cottonwoods have been shown to be dependent on water originating from streamflow because precipitation is lower than potential evapotranspiration. As a result, groundwater in riparian zones is typically only available because of stream recharge (Rood et al. $2003 a$ ). Cottonwoods are typically found only $3-4 \mathrm{~m}$ above the base stage of the river. Therefore, the location of cottonwood relative to the river is generally related to elevation more often than distance directly (Stromberg \& Patten 1996). We did not see a difference in the number of juveniles or the percent of top-killed adults that formed basal resprouts relative to either elevation or distance from the river channel. Ellis (2001) found similarly that resprout rate did not differ with distance from the channel, they attributed this to a shallow water table under the entire floodplain, which is consistent with conditions at the Cimarron National Grassland where groundwater is typically found between 30 and $45 \mathrm{~cm}$ below the surface. The availability of groundwater throughout the burned area could explain the high number of $P$. deltoides juveniles in our study. The lack of difference in number of juveniles or percent top-killed adults relative to elevation might be the result of readily available groundwater throughout the site. However, it might also be the case that the resolution of the elevation data available for the 
study site might not be fine enough to capture the microsite variation driving resprouting response. Depth to groundwater was not reported in studies that found poor resprouting of $P$. deltoides and other section Aigeiros cottonwood following fire (Gom \& Rood 1999, 2000; Rood et al. 2007).

Other factors potentially contributing to differential responses of $P$. deltoides to fire include the age of the stand, the intensity of the fire, the timing of the burn, the competitive influence of neighboring species, differential patterns in the environmental variables controlling channel morphology among sites, and phenotypic differences in populations of $P$. deltoides. Individuals at Cimarron National Grassland likely became established between 1953 and 1991 given the history of riparian vegetation in that section of the Cimarron River (Schumm \& Lichty 1963; VanLooy \& Martin 2005), making them between 20 and 60 years old. $P$. deltoides individuals are thought to lose their ability to resprout after the first several decades (Friedman \& Lee 2002). However, the individuals resprouting following the Tunner Fire were likely more than several decades old, suggesting that, while age might play a role in determining the potential for resprouting, it is not an absolute determinant. Therefore, it is likely that many variables are interacting to drive $P$. deltoides resprouting responses, including climatic, demographic, and environmental contexts as well as pre- and post-wildfire conditions.

Fire effects generally are context dependent and can vary widely depending on location and pre- and post-fire conditions (Spies et al. 2006). Studies that found $P$. deltoides to be a weak resprouter in the Great Plains (Gom \& Rood 1999, 2000; Rood et al. 2007) were conducted in areas with different channel morphology as a result of different climatic conditions, sediment supply, and flow variability than southwestern Kansas (Friedman et al. 1997). This has been shown to influence riparian forest responses to altered disturbance regimes, such as reduced peak flows from damming, and therefore could play a role in mediating responses to other disturbances such as fire (Friedman et al. 1997). However, even within a region where channel morphology likely did not vary, both Ellis (2001) and Smith et al. (2009) found variable amounts of resprouting in different locations. This suggests that not only climate, but also local environmental conditions, such as available groundwater, as well as the demographic condition of the stand, might play a role in post-fire resprouting response.

In addition to differing climate and environmental conditions, post-wildfire stand management could play a role in determining $P$. deltoides regeneration following wildfire. For instance, the effects of post-wildfire salvage on cottonwood regeneration are relatively unknown. Herbivory has also been shown to limit cottonwood recruitment, while native browsers did not limit recruitment in Cimarron National Grassland and grazers are excluded from the riparian area, other studies have found associations between lack of cottonwood recruitment and elk herbivory on cottonwood seedlings and resprouts (Beschta 2003, 2005). Therefore, differences in regeneration among studies could be associated with differential amounts of native browsing or livestock grazing pressure. More post-wildfire studies of cottonwood regeneration across a broad geographic range and a broad range of contexts, which allow sufficient time for recovery and regeneration, are necessary to determine the drivers of variability in $P$. deltoides resprouting.

Identifying potential paths toward self-sustaining regeneration in cottonwood stands is important because reliance on intensive restoration actions in an attempt to control complex adaptive systems often does not work in the long run (Allen et al. 2002; Beechie et al. 2010). If new tree plantings are fundamental to cottonwood riparian forest regeneration and persistence (because of a presumed lack of resprouting), then long-term investments in new plantings will be an ongoing component of silvicultural plans. However, even if planted seedlings survive to adult ages, additional management will be necessary to retain larger individuals in the face of large-scale and intense disturbances (e.g. fire) and also to remove invasive species (e.g. tamarisk) that affect cottonwood recruitment and life stage transitions. This cycle of planting of new trees and the subsequent protection of those trees as they get older is a classic signature of a command and control approach to natural resource management-success at one demographic stage forces sequential control efforts at later demographic stages (Folke 2006; Allen et al. 2014). The unintended consequence of command and control management is that it results in population synchrony over a landscape, which can increase the likelihood that large-scale perturbations such as drought, invasion, disturbance, or pest outbreaks will collapse the very resource intensive restoration actions were meant to protect (Messier et al. 2015).

An alternative approach is to manage for critical types and ranges of variability in disturbance regimes (Holling \& Meffe 1996). With decreased flooding in the Great Plains and an increase in the incidence and severity of wildfire (Donovan et al. 2017), the importance of understanding $P$. deltoides response to wildfire across a range of conditions is imperative if $P$. deltoides riparian forests are to persist in the face of altered disturbance regimes. While our study shows that germination and short-term establishment of juveniles as well as basal resprouting are possible following fire, further research is needed to determine the potential for long-term survival of these individuals. In addition, given the variability in cottonwood response to fire, more research is needed to determine the conditions under which recruitment can occur following fire. If it is determined that $P$. deltoides forest regeneration can occur following fire, fire regime restoration could provide a more cost-effective means for creating asynchronous age-classes over large areas of riparian forest than currently applied command-and-control approaches. The potential for increased asynchrony in stand age are indicated by a combination of data from burned and unburned plots at Cimarron National Grassland. Burned plots are characterized by high density of resprouting mature trees and juveniles and a highly left-skewed age distribution, while unburned plots have a bimodally distributed age structure. If the juveniles continue to survive and are capable of replacing the burned stand, combining these patch types across a landscape results in an overall more even distribution of age classes, although age classes would be patchily distributed across the landscape. This provides a mosaic of asynchronously dynamic cottonwood patches. Asynchrony among local populations, 
while increasing local extinction probability, has been shown to increase overall stability by reducing global extinction probability (Heino et al. 1997; Palmqvist \& Lundberg 1998). In addition, fire has been shown to be an effective tool for limiting biological invasions without employing intensive mechanical means, which require constant reapplication for species that reproduce prolifically such as cedar, or resprout following mechanical removal such as tamarisk (Holling \& Meffe 1996). We found $P$. deltoides regeneration to be higher than tamarisk regeneration in areas burned by the wildfire and tamarisk regeneration to be higher in unburned plots. This suggests that under some conditions, wildfire might provide a means of increasing the persistence of $P$. deltoides in areas where mortality of cottonwood might otherwise lead to the replacement of cottonwood by tamarisk.

The life history strategy of cottonwoods evolved in response to the specific climate stressors and disturbance regimes at a given location. Disturbance regimes include temporal and spatial components as well as the intensity profile of disturbance through time and space (Turner et al. 1997). Given their location along prairie river floodplains, in the Great Plains many $P$. deltoides stands likely would have been exposed to relatively frequent low intensity fires and occasional high intensity fires were also likely throughout much of the range of cottonwood, especially the more arid portions of its range, given the propensity for drought and subsequent low fuel moisture content in these areas (Dwire \& Kauffman 2003). This is evidenced by widespread contemporary incidences of high intensity fires that burn through riparian cottonwood stands and historical fire scar data from cottonwood forests (Mahoney \& Rood 1998). In addition, cottonwoods have thick bark that makes them more fire resistant (Hengst \& Dawson 1993), suggesting that fire played some role in their evolutionary history. Clonal sprouting provides the primary route for recruitment in a habitat that is consistently exposed to a range of intensities in physical disturbance, providing opportunities for recruitment during periods when seedling production is limited due to the intensity of disturbance (Gom \& Rood 2000; Rood et al. 2007). Given this, regeneration through vegetative growth could be essential to the persistence of some riparian cottonwood communities. It is estimated that even without any seedling establishment for long periods of time, cottonwood forests can regenerate entirely through resprouting (Shaw 1976).

There is a need for a greater network of post-wildfire surveys that explore the mechanisms of divergent responses of $P$. deltoides under a range of environmental and climatic conditions. In addition, longer-term studies are necessary to determine the potential for resprouting to result in recruitment to adult cottonwood stands. Such an approach would enhance our understanding of conditions under which $P$. deltoides can persist following wildfire, ensuring cottonwood persistence in a future with uncertain global drivers. More broadly, extending these findings to other resprouting riparian forest species suggests the importance of better understanding riparian forest response to disturbance across a range of conditions in order to develop self-sustaining restoration strategies in areas where intensive restoration interventions could be untenable.

\section{Acknowledgments}

We would like to thank Lance Brown for input and logistical assistance during the course of this study. We thank Brice Hanberry for conversations that aided in the development of this manuscript and we also thank Rebecca Brown, Stewart Rood, and two anonymous reviewers for input that substantially improved this manuscript. We would also like to thank Jack Arterburn, Callie Griffith, and Jonathan Soper for assistance in the field and Maribeth Milner for map creation and assistance with GIS.

\section{LITERATURE CITED}

Allen CD, Savage M, Falk DA, Suckling KF, Swetnam TW, Schulke T, Stacey PB, Morgan P, Hoffman M, Klingel JT (2002) Ecological restoration of southwestern ponderosa pine ecosystems: a broad perspective. Ecological Applications 12:1418-1433

Allen CR, Angeler DG, Garmestani AS, Gunderson LH, Holling CS (2014) Panarchy: theory and application. Ecosystems 17:578-589

Beechie TJ, Sear DA, Olden JD, Pess GR, Buffington JM, Moir H, Roni P, Pollock MM (2010) Process-based principles for restoring river ecosystems. BioScience 60:209-222

Benjamini Y, Hochberg Y (1995) Controlling the false discovery rate: a practical and powerful approach to multiple testing. Journal of the Royal Statistical Society Series B (Methodological) 57:289-300

Beschta RL (2003) Cottonwoods, elk, and wolves in the Lamar Valley of Yellowstone National Park. Ecological Applications 13:1295-1309

Beschta RL (2005) Reduced cottonwood recruitment following extirpation of wolves in yellowstone's northern range. Ecology 86:391-403

Borcard D, Legendre P (2002) All-scale spatial analysis of ecological data by means of principal coordinates of neighbour matrices. Ecological Modelling 153:51-68

Borcard D, Legendre P, Drapeau P (1992) Partialling out the spatial component of ecological variation. Ecology 73:1045-1055

Borcard D, Legendre P, Avois-Jacquet C, Tuomisto H (2004) Dissecting the spatial structure of ecological data at multiple scales. Ecology 85:1826-1832

Colorado State Forest Service (2015) Cottonwood management: ecology, rehabilitation, wildfire and other considerations. FM2015-1 Warner College of Natural Resources, Colorado State University, Fort Collins, Colorado, U.S.A.

Donovan VM, Wonkka CL, Twidwell D (2017) Surging wildfire activity in a grassland biome. Geophysical Research Letters 44:5986-5993. https://doi .org/10.1002/2017GL072901

Dray S, Legendre P, Peres-Neto PR (2006) Spatial modelling: a comprehensive framework for principal coordinate analysis of neighbour matrices (PCNM). Ecological Modelling 196:483-493

Dreesen D, Harrington J, Subirge T, Stewart P, Fenchel G (2002) Riparian Restoration in the southwest: Species Selection, Propagation, Planting Methods, and Case Studies. USDA Forest Service, Rocky Mountain Research Station Proceedings RMRS-P-24 Fort Collins, Colorado, U.S.A.

Dwire KA, Kauffman JB (2003) Fire and riparian ecosystems in landscapes of the western U.S.A. Forest Ecology and Management 178:61-74

Ellis LM (2001) Short-term response of woody plants to fire in a Rio Grande riparian forest, Central New Mexico, U.S.A. Biological Conservation 97:159-170

Fick WH, Geyer WA (2010) Cut-stump treatment of saltcedar (Tamarix ramosissima) on the Cimarron National Grasslands. Transactions of the Kansas Academy of Science 113:223-226

Folke C (2006) Resilience: the emergence of a perspective for social-ecological systems analyses. Global Environmental Change 16:253-267

Friedman JM, Lee VJ (2002) Extreme floods, channel change, and riparian forests along ephemeral streams. Ecological Monographs 72:409-425 
Friedman JM, Scott ML, Auble GT (1997) Water management and cottonwood Forest dynamics along prairie streams. Pages 49-71. In: Knopf FL, Samson FB, (eds) Ecology and conservation of Great Plains vertebrates. Ecological Studies. Springer, New York

Friedman JM, Auble GT, Shafroth PB, Scott ML, Merigliano MF, Freehling MD, Griffin ER (2005) Dominance of non-native riparian trees in western U.S.A. Biological Invasions 7:747-751

Gom LA, Rood SB (1999) Patterns of clonal occurrence in a mature cottonwood grove along the Oldman River, Alberta. Canadian Journal of Botany $77: 1095-1105$

Gom LA, Rood SB (2000) Fire induces clonal sprouting of riparian cottonwoods. Canadian Journal of Botany 77:1604-1616

González E, Sher AA, Tabacchi E, Masip A, Poulin M (2015) Restoration of riparian vegetation: a global review of implementation and evaluation approaches in the international, peer-reviewed literature. Journal of Environmental Management 158:85-94

Guyette RP, Stambaugh MC, Marschall J, Abadir E (2015) An analytic approach to climate dynamics and fire frequency in the Great Plains. Great Plains Research 25:139-150

Heino M, Kaitala V, Ranta E, Lindström J (1997) Synchronous dynamics and rates of extinction in spatially structured populations. Proceedings of the Royal Society B: Biological Sciences 264:481-486

Hengst EE, Dawson JO (1993) Bark properties and fire resistance of selected tree species from the central hardwood region of North America. Canadian Journal of Forest Research 24:688-696

Holling CS, Meffe GK (1996) Command and control and the pathology of natural resource management. Conservation Biology 10:328-337

Howe WH, Knopf FL (1991) On the imminent decline of Rio Grande cottonwoods in central New Mexico. The Southwestern Naturalist 36:218-224

Irvine JR, West NE (1979) Riparian tree species distribution and succession along the lower Escalante River, Utah. The Southwestern Naturalist 24:331-346

Kansas Water Office (2005) 10-year strategic plan for the comprehensive control of tamarisk and other non-native phreatophytes, Tamarisk 10-Year Strategic Plan Working Group Topeka, KS WR 1.2:T 153

Legendre P (1993) Spatial autocorrelation: trouble or new paradigm? Ecology $74: 1659-1673$

Lytle DA, Merritt DM (2004) Hydrologic regimes and riparian forests: a structured population model for cottonwood. Ecology 85:2493-2503

Mahoney JM, Rood SB (1998) Streamflow requirements for cottonwood seedling recruitment — an integrative model. Wetlands 18:634-645

Messier C, Puettmann K, Chazdon R, Andersson KP, Angers VA, Brotons L, Filotas E, Tittler R, Parrott L, Levin SA (2015). From management to stewardship: viewing forests as complex adaptive systems in an uncertain world. Conservation Letters 8:368-377

Molles MC, Crawford CS, Ellis LM, Valett HM, Dahm CN (1998) Managed flooding for riparian ecosystem restoration. BioScience 48:749-756

National Oceanic and Atmospheric Administration (2016) Climate data online. https://www.ncdc.noaa.gov/ (accessed 1 Jan 2017)

Nemec KT, Allen CR, Helzer CJ, Wedin DA (2013) Influence of richness and seeding density on invasion resistance in experimental tallgrass prairie restorations. Ecological Restoration 31:168-185

Palmer MA, Reidy Liermann CA, Nilsson C, Flörke M, Alcamo J, Lake PS, Bond N (2008) Climate change and the world's river basins: anticipating management options. Frontiers in Ecology and the Environment 6:81-89

Coordinating Editor: Rebecca Brown
Palmqvist E, Lundberg P (1998) Population extinctions in correlated environments. Oikos 83:359-367

Rood SB, Mahoney JM (1990) Collapse of riparian poplar forests downstream from dams in western prairies: probable causes and prospects for mitigation. Environmental Management 14:451-464

Rood SB, Braatne JH, Hughes FM (2003a) Ecophysiology of riparian cottonwoods: stream flow dependency, water relations and restoration. Tree Physiology 23:1113-1124

Rood SB, Gourley CR, Ammon EM, Heki LG, Klotz JR, Morrison ML, Mosley D, Scoppettone GG, Swanson S, Wagner PL (2003b) Flows for floodplain forests: a successful riparian restoration. BioScience 53:647-656

Rood SB, Goater LA, Mahoney JM, Pearce CM, Smith DG (2007) Floods, fire, and ice: disturbance ecology of riparian cottonwoods the review is one of a selection of papers published in the special issue on poplar research in Canada. Botany 85:1019-1032

Schier GA, Campbell RB (1976) Differences among Populas species in ability to form adventitious shoots and roots. Canadian Journal of Forest Research 6:253-261

Schumm SA, Lichty RW (1963) Channel widening and flood-plain construction along Cimarron River in southwestern Kansas. Geological Survey Professional 352-D. US Government Printing Office, Washington D.C.

Shaw RK (1976) A taxonomic and ecologic study of the riverbottom forest on St. Mary River, Lee Creek, and Belly River in southwestern Alberta, Canada. The Great Basin Naturalist 36:243-271

Smith DG, Pearce CM (2000) River ice and its role in limiting woodland development on a sandy braid-plain, Milk River, Montana. Wetlands 20:232-250

Smith DM, Finch DM, Gunning C, Jemison R, Kelly JF (2009) Post-wildfire recovery of riparian vegetation during a period of water scarcity in the southwestern U.S.A. Fire Ecology 5:38-55

Spies TA, Hemstrom MA, Youngblood A, Hummel S (2006) Conserving old-growth forest diversity in disturbance-prone landscapes. Conservation Biology 20:351-362

Stambaugh MC, Guyette RP, McMurry ER, Cook ER, Meko DM, Lupo AR (2011) Drought duration and frequency in the U.S. corn belt during the last millennium (AD 992-2004). Agricultural and Forest Meteorology 151:154-162

Stromberg JC, Patten DT (1996) Instream flow and cottonwood growth in the eastern sierra Nevada of California, U.S.A. River Research and Applications 12:1-12

Sudbrock A (1993) Tamarisk control I. Fighting back: an overview of the invasion, and a low-impact way of fighting it. Ecological Restoration 11:31-34

Turner MG, Dale VH, Everham EH III (1997) Fires, hurricanes, and volcanoes: comparing large disturbances. Bioscience 47:758-768

Twidwell D, Fuhlendorf SD, Engle DM, Taylor Jr, CA (2009). Surface fuel sampling strategies: linking fuel measurements and fire effects. Rangeland Ecology \& Management 62(3), 223-229

U.S. Geological Survey (2016) National Water Information System data available on the World Wide Web (USGS Water Data for the Nation). (accessed 1 Jan 2017)

VanLooy JA, Martin CW (2005) Channel and vegetation change on the Cimarron River, southwestern Kansas, 1953-2001. Annals of the Association of American Geographers 95:727-739

Wand M (1997) Data-based choice of histogram bin width. The American Statistician 51:59-64
Received: 22 June, 2016; First decision: 1 August, 2016; Revised: 26 June, 2017; Accepted: 30 June, 2017 